\title{
First evidence for the snake-eyed skink Ablepharus kitaibelii (Bibron et Bory de Sant-Vincent, I833) (Sauria Scincidae) in Astypalea Island (Dodecanese, Greece)
}

\author{
Mauro Grano ${ }^{*}$ \& Cristina Cattaneo² \\ ${ }^{1}$ Coordinator of Lazio Section Societas Herpetologica Italica \\ ${ }^{2}$ Via Eleonora d'Arborea 12, 00162 Rome, Italy \\ "Corresponding author, e-mail: elaphe58@yahoo.it
}

\begin{abstract}
The first documentation (also with photos) on the presence of the snake-eyed skink Ablepharus kitaibelii (Bibron et Bory de Saint-Vincet, 1833) (Sauria Scincidae) in Astypalea Island (Dodecanese, Greece) is provided here. Until now, only five specimens in the Natural History Museum of Crete were known.
\end{abstract}

KEY WORDS

Ablepharus kitaibelii; Astypalea; Dodecanese; Snake-eyed skink.

Received 13.01.2019; accepted 19.02.2019; published online 28.02.2019

\section{INTRODUCTION}

The snake-eyed skink Ablepharus kitaibelii (Bibron et Bory de Saint-Vincent, 1833) (Sauria Scincidae) is the only species of the genus distributed in Europe and shows a distribution from southern Slovakia and Hungary, through most of Serbia, the eastern parts of continental Croatia, southern Romania, Bulgaria, Macedonia, Albania (lowland areas), Turkey (western and central), and Greece (Mainland, and many Ionian and Aegean Islands). As regards its range in the Aegean Islands, on Kos, Leros, Makronisi (SW of Lipsi), Nisyros, Tilos (Masseti, 1999), Chalki, Alimia, Symi, and Rhodes, it occurs with the nominate form $\mathrm{A}$. $\mathrm{ki}$ taibelii kitaibelii (Bibron et Bory, 1833). On Karpathos, Kasos, Armathia, and Mikronisi (islets of Crete), A. kitaibelii fabichi Štěpánek, 1937 is present. On the island group of Kastellorizo and on the opposite southwest coast of Turkey, a cryptic species has been identified that seems to belong to a clade with features of both $A$. kitaibelii and $A$. budaki, and which could be ascribed to $A$. budaki anatolicus Schmidtler, 1997 (Skourtanioti et al., 2016).

The occurrence of the snake-eyed skink $A$. kitaibelii in the Aegean Island of Astypalea (Dodecanese, Greece) is here reported for the first time.

\section{MATERIAL AND METHODS}

The data here presented came from field observation made by the authors on Astypalea Island during two different periods: August 2015 and April 2016. The individuals encountered were not captured or manipulated, but simply photographed in accordance with the Greek National Legislation (Presidential Decree 67/81). During the investigations, some young individuals of $A$. kitaibelii were sighted: a few in the immediate vicinity of a well located under the dam near the village of Livadhi, others along a boundary wall of an orchard inside Livadhi village (Fig. 1). Both situations were char- 
acterized by moisture, supporting the hypothesis that $A$. kitaibelii is mainly a hygrophilous species. The individuals detected on Astypalea Island exhibited tails with orange-bright red colours (Fig. 2 ). Normally, the underside is greenish-blue or grey-white and in Transcaucasian and Thracian populations it appears reddish-orange (Gruber, 1981). As in the case with Anatololacerta pelasgiana on Tilos Island (Grano et al., 2018), a recent introduction can be assumed, since the only detected individual have been found in the immediate vicinity of Livadhi, the first most developed village on the island.

\section{RESULTS AND CONCLUSIONS}

Five specimens of $A$. kitaibelii from Astypalea Island preserved in the Natural History Museum of Crete (NHMC 80.3.82.25; NHMC80.3.82.256; NHMC80.3.82.257; NHMC80.3.82.85; NHMC 80.3.82.86) are known, but these data have not been published.

According to the Aegean distribution of this skink, it is likely to assume that on Astypalea Island the nominate form A. kitaibelii kitaibelii occurs. Ablepharus kitaibelii appears to be mainly a hygrophilous species (Cattaneo, 1998), as it generally lives on wet soil and in underwood bedding of

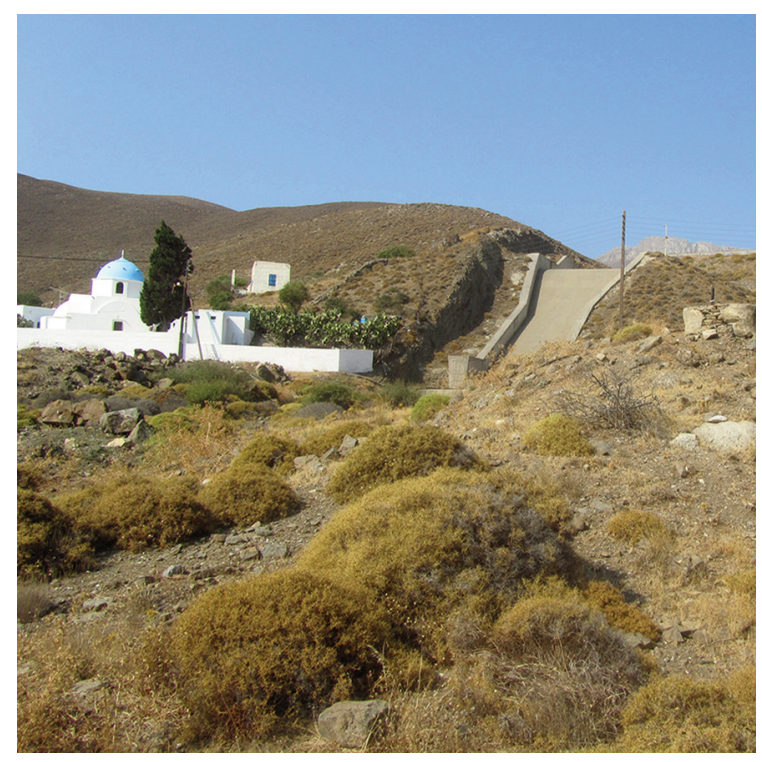

Figure 1. Study area near Livadhi village (Astypalea Island, Dodecanese, Greece). conifers forests (Broggi, 2002; Wilson \& Grillitsch, 2009). It was also observed in inhabited areas, probably driven by increased moisture. Astypalea looks like an enigmatic island because, despite its size and its discrete environmental heterogeneity, does not host snakes. Until now, only four lizards have been recorded in the island: Hemidactylus turcicus (Linnaeus, 1758), Mediodactylus kotschyi (Steindachner, 1870), Podarcis erhardii (Bedriada, 1876), Ophisops elegans Ménétries, 1832 and one frog: Pelophylax bedriagae (Camerano, 1882).

The island is essentially hilly and is mainly characterized of limestone, whereas the area between the orographic series of the Mesa and the Exo Nisi (eastern and western part of the island) is constituted by flysch. Astypalea is mainly dry, but its karstic nature has given origin to water sources, especially in the western area. Moreover, in the Exo Nisi near Livadhi, there is a reservoir with a depth of 25 meters to supply water to the island. Astypalea suffers since ancient times of strong overgrazing by domestic and wild goats. In the past, the island was rich in forests, which have been destroyed by humans to use as farmland and pastures and as fuel in the lime kilns, which played a key role in the economy of Astypalea (Cattaneo \& Grano, 2016). This probably led to an impoverishment of the local herpetofauna, as it was shown for the lizard of the genus Podarcis Wagler, 1830 (Pafilis et al., 2013). Despite a relatively longstanding tradition of herpetological research on the Greek islands (Pafilis, 2010), Astypalea ranks among those less considered, as there are no records of amphibians and reptiles with full field details available from the island (Uhrin \& Benda, 2018).

Contributions relating data on herpetofauna of this island are provided by Zavattari (1929), Wettstein $(1937,1953)$, Beutler \& Gruber (1977) and Angelici et al. (1990). Recently, an update on the presence of Mediodactylus kotschyi and Hemidactylus turcicus on this island has been published by Uhrin \& Benda (2018).

\section{ACKNOWLEDGEMENTS}

The authors would like to thank M.A.L. Zuffi (Pisa, Italy) for the scientific review and A. Cattaneo (Roma, Italy) for his invaluable help. 


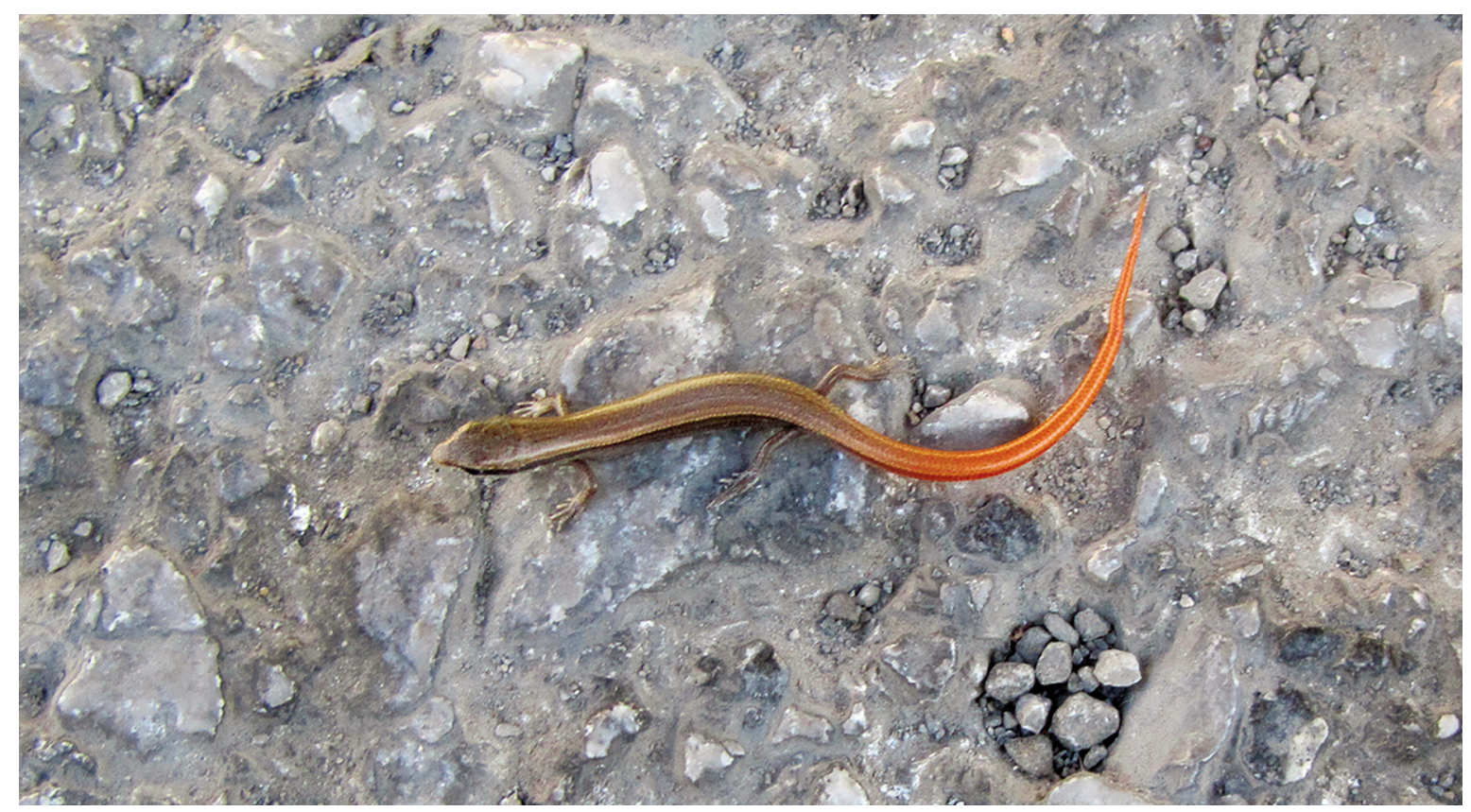

Figure 2. Ablepharus kitaibelii from Livadhi village (Astypalea Island, Dodecanese, Greece).

\section{REFERENCES}

Angelici F.M., Capula M. \& Riga F., 1990. Notes on the herpetofauna of Astipalaia Island (Dodecanese, Greece). British Herpetological Society Bulletin, 34: 31-33.

Beutler A. \& Gruber U., 1977. Intraspezifische Untersuchungen an Cyrtodactylus kotschyi (Steindachner, 1870): Reptilia: Gekkonidae. Beitrag zu einer mathmatischen Definition des Begriff Unterart, Spixiana, München, 1: 165-202.

Broggi M.F., 2002. Herpetological notes on the Dodecanese islands of Symi and Sesklia (Greece). Herpetozoa, 15: 186-187.

Cattaneo A., 1998. Gli Anfibi e i Rettili delle isole greche di Skyros, Skopelos e Alonissos (Sporadi settentrionali). Atti Società Italiana di Scienze Naturali del Museo civico di Storia naturale di Milano, 139: $127-$ 149.

Cattaneo C. \& Grano M., 2016. Contribution to the knowledge of vascular flora on Astypalea Island (Dodecanese, Greece). Phytologia Balcanica, 22: 405417.

Grano M., Cattaneo C. \& Cattaneo A., 2018. Nuovo contributo alla conoscenza dell'erpetofauna dell'isola egea di Tilos (Dodecaneso, Grecia) (Amphibia et Reptilia). Il Naturalista siciliano, 42: 3-13.

Gruber U., 1981. Ablepharus kitaibelii Bibron und Bory 1833. Johannisechse. In: Boehme W. (Ed.), Hand- buch der Reptilien und Amphibien Europas, Bd. I, Echsen I, Akademische Verlagsgesellschaft, Wiesbaden, pp. 292-307.

Masseti M., 1999. Terrestrial vertebrate fauna on Mediterranean islands: Tilos (Dodecanese, Greece) a case study. Abstracts of the 8th International Congress on the Zoogeography and Ecology of Greece and Adjacent Regions. Kavala, 172-1 May 1999. The Hellenic Zoological Society, Athens: 94.

Pafilis P., 2010. A brief history of Greek herpetology. Bonn Zoological Bulletin, 57: 329-345.

Pafilis P., Anastasiou I., Sagonas K. \& Valakos E.D., 2013. Grazing by goats on islands affects the populations of an endemic Mediterranean lizard. Journal of Zoology, 290: 255-264.

Skourtanioti E., Kapli P., Ilgaz C., Kumlutaş Y., Avci A., Ahmadzadeh F., Isailović J.C.N., Gherghel I., Lymberakis P. \& Poulakakis N., 2016. A reinvestigation of phylogeny and divergence times of the Ablepharus kitaibelii species complex (Sauria, Scincidae) based on mtDNA and nuDNA genes. Molecular Phylogenetics and Evolution, 103: 199214. https://doi.org/10.1016/j.ympev.2016.07.005

Uhrin M. \& Benda P., 2018. New records of Mediodactylus kotschyi and Hemidactylus turcicus (Squamata: Gekkonidae) from Astypalea Island, Greece. Herpetology Notes, 11: 275-278.

Wettstein O., 1937. Vierzehn neue Reptilienrassen von den südlichen Ägäischen Inseln. Zoologischer Anzeiger, 118: 79-90. 
Wettstein O., 1953. Herpetologia Aegaea. Sitzungsberichte der Akademie der Wissenschaften, mathematisch-naturwissenschaftliche Klasse, 162: 651-833.

Wilson M.J. \& Grillitsch H., 2009. The herpetofauna of
Simi (Dodecanese, Greece) (Amphibia, Reptilia). Herpetozoa, 22: 99-113.

Zavattari E., 1929. Ricerche faunistiche nelle Isole Italiane dell'Egeo. Anfibi e Rettili. Archivio Zoologico Italiano, 13: 31-36. 